\title{
48. A LISTRIC FAULT MODEL FOR THE FORMATION OF THE DIPPING REFLECTORS PENETRATED DURING THE DRILLING OF HOLE 642E, ODP LEG 104
}

\author{
Ian L. Gibson ${ }^{2}$ and David Love ${ }^{2,3}$
}

\section{INTRODUCTION}

Site 642, drilled during Leg 104 of the Ocean Drilling Program, is located near the outer margin of the Vøring Plateau in the Norwegian Sea. One of the primary objectives of the leg was to examine the nature of the dipping reflectors which characterize the outer margin of the Plateau, near the continent/ocean transition (Hinz and Weber, 1976; Hinz and Schlüter, 1978; Talwani, 1978; Eldholm et al., 1979; Talwani et al., 1981). Reflectors stratigraphically above the base reflector $\mathrm{K}$ were interpreted by most investigators as a thick dipping series of lavas which were erupted before, or during, the initial stages of the formation of the Norwegian Sea (Mutter et al., 1982; Talwani et al., 1983; Hinz et al., 1984). This interpretation was supported by the results from Site 642 , where drilling penetrated a $310-\mathrm{m}$ thick cover of Cenozoic hemipelagic sediments overlying a $760-\mathrm{m}$ succession of upper series lavas above reflector K. Although $142 \mathrm{~m}$ of lower series flows were drilled below this reflector, the base of the lava succession was not reached, and the nature of the crustal section beneath the flows is unknown. In addition, the mode of formation of the pile and the origin of the dipping structure is uncertain.

In this short note we review the available evidence on the nature of the Vøring Plateau lavas. We then briefly discuss critical features of comparable subaerial lava piles exposed on other continental margins in the North Atlantic and in Iceland. Finally, we comment on the nature of the continent/ocean transition and propose a model to explain the geometry of the pile.

\section{DIPPING REFLECTORS OF THE VORING PLATEAU}

\section{The Geometry of the Lava Pile}

The results of a multichannel seismic reflection survey along a NW-SE line through Site 642 are reproduced in Figure 7 of Eldholm, Thiede, and Taylor (1987). This section shows the more important structural features of the dipping reflectors which occur landward of anomalies 24A and 24B, and are thus probably Eocene in age.

Study of well-defined and relatively closely spaced reflector pairs within the dipping succession indicates that the intervening sequence is thin near the upper surface of the lava pile, but thickens down dip. The change in thickness is progressive and accompanied by a change in the angle of dip. At the top of the lava pile the flows are almost horizontal, whereas the true dip is steepest at the base of the section, where the reflectors begin to lose their identity.

A second feature of significance is that the reflectors appear to die out downward. The termination is in part apparent, and a

\footnotetext{
${ }^{1}$ Eldholm, O., Thiede, J., Taylor, E., et al., 1989. Proc. ODP, Sci. Results, 104: College Station, TX (Ocean Drilling Program).

2 Department of Earth Sciences, University of Waterloo, Waterloo, Ontario, N2L 3G1, Canada.

${ }^{3}$ Now at Dept. of Geological Sciences, Queen's University at Kingston, Kingston, Ontario K7L3N6, Canada.
}

function of the decreasing sensitivity of the seismic method. However, the reflectors do not appear to terminate at a detectable faulted contact or lithologic boundary.

The dipping reflector lava succession is largely unfaulted, with individual horizons showing unbroken lateral continuity over distances in excess of $20 \mathrm{~km}$. This is in marked contrast to the earlier style of deformation in the Vøring Basin immediately to the west, which is characterized by block faulting and rapid subsidence in Late Jurassic and Early Cretaceous times (Eldholm et al., 1984).

\section{The Mode of Eruption and Chemistry of the Lavas}

The core from Site 642 provides a sample of the lavas that make up the stratigraphically lower part of the dipping reflector section. The $902-\mathrm{m}$ thick volcanic section consists of about 146 individual lava flows with some intercalated volcaniclastic layers. The flows have been divided into an upper series of $760 \mathrm{~m}$, and a thinner lower series of $142 \mathrm{~m}$, on the basis of geochemical studies (Viereck et al., Parson et al., this volume). The absence of pillowed flows, the red weathering horizons between many of the lavas, the scarcity of pelagic marine microfossils in the intercalated volcaniclastic sediments, and the general fluviatile character of those sediments, suggests that most, if not all, of the succession was erupted under subaerial conditions.

The geometry of flows erupted under subaerial and submarine eruptive conditions is completely different. Subaerial flood basalt flows are very extensive, often covering over $100 \mathrm{~km}^{2}$ (Greeley, 1977). Although submarine basaltic sheetflows do occur, the more common pillowed lavas tend to form mound-like piles usually less than $10 \mathrm{~km}$ in diameter (Ballard and van Andel, 1977).

The Leg 104 upper series flows are aphyric to moderately plagioclase and olivine-phyric. Major-, trace-, and rare-earth-element data show that these rocks have a very uniform $\mathrm{N}$-type MORB composition. The flows are very comparable in composition to basalts from some of the terrestrial lava piles formed during the early extensional history of the North Atlantic (Viereck et al., this volume).

\section{Dikes}

Shipboard studies identified only seven possible dikes cutting the lava succession. However, subsequent analysis suggests that only in two cases, near the base of the section, do the dikes contrast in composition with the bounding flows (Eldholm, Thiede, and Taylor, 1987). The nature of the remaining five intrusions remains uncertain. Certainly the proportion of dikes to lavas is very low. This is perhaps not surprising for a section drilled through the topographically higher part of a basalt lava pile.

\section{The Nature of the Underlying Basement}

The basement stratigraphically underlying the lavas at Site 642 has not been penetrated by drilling. However, an important observation made by the shipboard party at Site 642 is the occurrence of significant quantities of quartz and mica of continental origin in the intercalated sediments of the lower series and the occurrence of a few fragments of leucocratic gneiss and 
quartz-mica schist in the lowest sediments drilled and within an ignimbritic unit (Eldholm, Thiede, and Taylor, 1987).

In addition, geochemical work (Parson et al., this volume) indicates that the composition of the lower series lavas has been seriously modified by the incorporation of a silicic melt fraction. The most reasonable interpretation is that this melt fraction was derived from an immediately underlying continental basement by partial melting during the initial stages of volcanism (Parson et al., this volume).

These two sets of observations suggest that the basement stratigraphically underlying the lavas is continental in character, an interpretation compatible with the seismic character of the basement, and favored in the original interpretation of Hinz (1981).

\section{COMPARISONS WITH OTHER NORTH ATLANTIC SUBAERIAL LAVA PILES}

Lava piles comparable in structure, composition, and age to the dipping reflector sequence of the Vøring Plateau are now known from other marginal areas of the North Atlantic, between about latitudes $55^{\circ}$ and $75^{\circ} \mathrm{N}$. In some cases these lava piles, and the immediately underlying basement, are exposed above sea level, allowing detailed examination of the nature and form of the lava pile. The distribution of these flows is shown in Figure 1 of a recent compilation by White et al. (1987).

\section{The East Greenland Atlantic Margin}

A thick flood basalt lava pile is developed and exposed on the coast of east Greenland between latitudes $68^{\circ}$ and $70^{\circ} \mathrm{N}$ (Brooks, 1973) and further north at $75^{\circ} \mathrm{N}$ (Upton et al., 1980, 1984). The flows are Eocene in age (Soper et al., 1976) and form a seaward-dipping succession resting with a well-defined unconformity on the underlying basement. Flows very comparable in composition to the Vøring Plateau lavas sampled at Site 642 occur within the East Greenland lava pile. However, the latter succession contains a much greater variety of rocks, including some highly alkalic lavas (Brooks et al., 1976). A series of marine-dipping reflectors, very comparable to those of the Vøring Plateau, occur seaward and in direct continuity with this exposed lava pile and appear to characterize almost all of the east Greenland coast as far north as latitude $75^{\circ} \mathrm{N}$ (White, 1987, Fig. 1).

The east Greenland Eocene lavas, which are generally unfaulted, are cut by a series of dike swarms (Brooks, 1973) which approximately parallel the coast. The intensity of dike injection is greatest in the lower parts of the pile and exceeds $50 \%$ in places.

\section{The European Atlantic Margin}

Tertiary subaerial volcanism during the opening of the North Atlantic was also very significant in northwest Britain (Emeleus, 1983) and in the Faeroe Islands, where relics of what were large subaerial basalt piles are exposed. In Scotland the flows rest on the Pre-Cambrian basement or on a thin intervening succession of sediments. These lavas do not form thick seawarddipping successions but are apparently related to volcanic centers that developed at some distance from the margin of the continent. However, dipping reflector sequences, comparable to those drilled on the Vøring Plateau, are known from the Rockall Plateau margin (Roberts et al., 1984) and from the Hatton Bank (White et al., 1987).

\section{Iceland}

The Icelandic lava pile is significantly younger than the Vøring Plateau succession, and the lavas were not erupted in a continental margin setting. Nevertheless, relations in Iceland are particularly instructive. At Myvatn (Lat. $65^{\circ} 36^{\prime} \mathrm{N}$; Long. $17^{\circ} \mathrm{W}$ ), on the Quaternary active volcanic zone, the structure is broadly synclinal. To the east, the older subaerial Tertiary lavas of eastern Iceland form a thick succession that dips at low angles to the west beneath the axial volcanic zone (Palmason and Saemundsson, 1974). In eastern Iceland, Walker (1960) was the first to demonstrate that individual lava stratigraphic units thicken down-dip with an increase in the number of flows. The progressive change is accompanied by an increase in the angle of dip from 1 to 2 degrees near the upper surface of the lava pile to 5 to 10 degrees at a depth of $1.5 \mathrm{~km}$ (Fig. 1). Palmason (1980) provided a kinematic model for the formation of the lava pile, the latter being strikingly similar in geometry to the Vøring Plateau dipping reflector succession. Others, particularly Mutter et al. (1984), have also noted the generally comparable nature of the two areas, and the similar velocity structure in the two regions.

Other specific points of similarity with the dipping reflector succession include the composition of the flows, the very significant lateral continuity of individual horizons, the paucity of dikes in the upper part of the Icelandic succession and the general absence of major faults cutting the lava pile (Walker, 1959; Gibson et al., 1966).

\section{DISCUSSION: THE FORMATION OF THE VØRING PLATEAU REFLECTORS}

Evidence obtained during Leg 104 at Site 642 proves that the reflectors are a series of subaerial tholeiitic flood basalt lavas which are Eocene in age and which were thus probably erupted during the initial stages of opening of the North Atlantic at about $55 \mathrm{Ma}$ (Eldholm, Thiede, and Taylor, 1987). Analogy with other areas, in particular with eastern Greenland and with data from Site 642 concerning the composition of the lower series, suggests that the flows constituting the westward dipping part of the dipping reflector section, i.e., those within Zone IIA (Eldholm et al., 1984), probably rest stratigraphically on the continental basement along a simple, gently seaward-dipping unconformity, perhaps separated from that basement by intervening sediments. However, assuming that the continental basement is present vertically beneath the base of Hole 642, what remains unclear is how far that basement extends to the west. Also uncertain is the mechanism by which the flows attained their dip.

The striking similarity in the structure of the eastern Iceland lava pile to the dipping reflector section suggests that the continental basement may be absent vertically below the dipping reflectors at the western edge of the Vøring Plateau. Although one cannot observe the deeper parts of the crustal section in Iceland, below the Icelandic lava pile there is probably a dike/gabbro complex which in turn rests on the upper mantle. We suggest that the same stratigraphy may characterize the western part of the Vøring Plateau lava pile. If this is true, the gently dipping unconformity at the base of the lava pile effectively separates an Icelandic type of oceanic crust from the Norwegian continental crust. As Skogseid and Eldholm (in press) note, the dipping surface marks the onset of subaerial sea-floor spreading with the flows initially covering continental and dike-injected continental crust and later veneering Icelandic-type oceanic crust. It is a matter of semantics as to where one draws the line separating the oceanic and the continental crust, as the boundary is transitional (White et al., 1987).

To the west of Site 642 , there is a transition from the dipping reflector, "Icelandic-type" crust to "normal" oceanic crust, characterized by linear magnetic anomalies. We follow Skogseid and Eldholm (in press) in suggesting that this transition represents a change from dominantly subaerial to submarine volcanism with an associated loss of significant lateral continuity in the flows, the change being achieved by subsidence of the crust.

The inclined homoclinal nature of the dipping reflector sequence cannot simply be ascribed to the progressive sagging of 


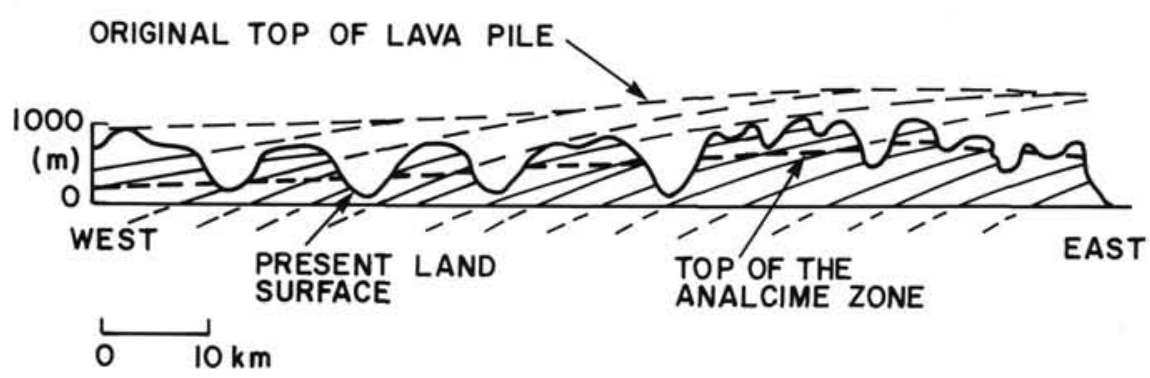

Figure 1. Diagrammatic section across the Tertiary lava pile of eastern Iceland, showing the inferred relationship of the original top of the lava pile to the lava stratigraphy and the mapped top of the analcime metamorphic zeolite zone. The observed upward reduction in the angle of dip is accompanied by the up-dip thinning of lava units (from Walker, 1960).

the lava pile during successive eruptions as was suggested by both Hinz (1981) and Mutter et al. (1982). The latter authors also tilted only the upper extrusive section of the crust, leaving the underlying dikes vertical. Clearly a more rigorous geometrical explanation is required. The upper part of the crust would behave in an essentially brittle fashion during the early stages of crustal extension. The mechanism for the development of the inclination of the lavas must also explain the rapid change from a continental to an "Icelandic-type" crustal section.

Normal listric faulting characterizes the deformation of many of the sedimentary basins formed in association with the opening of the North Atlantic (Gibbs, 1984). We suggest that the inclination of the dipping reflector lavas is a result of rotation about similar listric normal faults which were formed as an integral part of the volcanism and the associated crustal extension. We are not the first to propose that the geometry of the westward-dipping reflector succession is the result of rotation about listric faults. Bally (1983) suggested that the reflectors were sediments progressively filling a half graben generated by a growth fault and a related listric detachment dipping toward the continent.

In our simplified model for the formation of the dipping reflector sequence, the initial lava flow is shown as being erupted onto the underlying basement from a dike. The latter also marks the line of a listric normal fault. The latter is vertical at the surface, but shallows, and is continuous with a listric detachment at depth. Deformation along the fault is assumed to accompany the eruption, with dike and lava filling the space produced by the extension and rotation along the fault plane (Fig. 2A). Although initially a single fault is developed, with further eruptions the faults will form a paired set; the lavas develop a generally synclinal structure about the eruption zone. The structure would thus have been similar to that observed in northern Iceland at the present time. During the initial stages, one would expect the early lavas to be contaminated by the passage of magmas through the continental crust and "contaminated flows," comparable to those of the lower series, would be erupted.

Subsequent eruptions from fissures parallel and adjacent to the initial dike are shown in Figure 2B. In this simplified model no intervening screens of the continental basement are developed and thus there is no transitional zone between the basement and the newly generated "Icelandic-type" oceanic crust. In fact, transitional zones of continental basement cut by intense mafic dike swarms may well underlie the basal lavas of the dipping reflector succession, in exactly the same way as they underlie parts of the Tertiary lava succession of east Greenland. The change from lower series lavas to flows of the upper series, with a marked reduction in the amount of crustal contamination, may mark when the feeding dikes and magma chambers are emplaced into earlier features of the same type and not directly into the continental crust.

The inclination of the lava pile that develops following a long series of such eruptions depends on the exact geometry of the listric fault surface and the amount of extension taken up by horizontal separation. We suggest that the geometrical relationships would have been similar to those prevailing in Iceland at the present time. This geometry with rather shallow dips appears to develop when the depth to the basal detachment is significantly less than the width of flexure associated with the curvature of the listric fault, and when, as in Iceland, significant extension is taken up by separation along the fault plane and the injection of dikes.

The result of repeated eruptions of this type is the formation of a thick homoclinal lava pile (Fig. 2C), underlain by a sheeted dike complex and some form of detachment surface. We show this diagrammatically as a single horizontal surface. In reality it is likely to be a series of such surfaces which may root back into older detachments formed during the extensional faulting of the pre-volcanic continental crust. Sellevoll and Mokhtari (1988) recognized such surfaces below the dipping reflectors, on the Lofoten margin, to the north of the Vøring Plateau.

The final transition to a normal oceanic crust is interpreted as a change in sea level relative to the eruptive surface. The changing geometry of the erupted lavas may have the result of changing the style of syn-volcanic deformation. However, we agree with Karson (1984) that listric faults are also likely to characterize typical mid-ocean ridge submarine volcanic activity.

In conclusion, we wish to emphasize that, although our interpretation is greatly simplified, it does stress the important similarities between the structural development of a dipping reflector continental margin and that of a non-volcanic, sedimented margin. Both are characterized by significant crustal attenuation which may be accommodated by listric normal faulting and associated flat-lying detachments. The only significant difference is that in the volcanic areas, extension is additionally taken up by the injection of dikes, leading to the formation of thick, dipping reflector, lava piles. White et al. (1987) and Eldholm, Thiede, and Taylor (1987) have both recently stressed that continental reconstructions show the North Atlantic volcanic margins grouped around the Eocene position of the Icelandic hot-spot.

\section{REFERENCES}

Ballard, R. D., and van Andel, T. H., 1977. Morphology and tectonics of the inner rift valley at Lat. $36^{\circ} 50^{\prime} \mathrm{N}$ on the Mid-Atlantic ridge. Geol. Soc. Am. Bull., 88:507-530.

Bally, A. W., 1983. Seismic expression of structural styles. AAPG Stud. Geol., 15:2. 
Brooks, C. K., 1973. Tertiary of Greenland-A volcanic and plutonic record of continental breakup. AAPG Mem., 19:150-160.

Brooks, C. K., Nielson, T.F.D., and Petersen, T. S., 1976. The Blossevile Coast Basalts of East Greenland: their occurrence, composition and temporal variations. Contrib. Mineral. Petrol., 58:279-292.

Eldholm, O., Sundvor, E., and Myhre, A., 1979. Continental margin off Lofoten-Vesteråelen, northern Norway. Mar. Geophys. Res., 4: 4-35.

Eldholm, O., Sundvor, E., Myhre, A. M., and Faleide, J. I., 1984. Cenozoic evolution of the continental margin off Norway and western Svalbard. In Spencer, A. M., et al. (Eds.), Petroleum Geology of the North European Margin: London (Graham and Trotman), 3-18.

Eldholm, O., Thiede, J., and Taylor, E., 1987. Evolution of the Norwegian continental margin: background and objectives. In Eldholm, O., Thiede, J., Taylor, E., et al., Proc. ODP, Init. Repts., 104: College Station, TX (Ocean Drilling Program), 5-25.

Eldholm, O., Thiede, J., Taylor, E., et al., 1987. Summary and preliminary conclusions, ODP Leg 104. In Eldholm, O., Thiede, J., and Taylor, E., Proc. ODP, Init. Repts., 104: College Station, TX (Ocean Drilling Program), 751-771.

Emeleus, C. H., 1983. Tertiary igneous activity. In Craig, G. Y. (Ed.), Geology of Scotland (2nd ed.): New York (Wiley), 357-397.

Gibbs, A. D., 1984. Structural evolution of extensional basin margins. J. Geol. Soc. London, 141:609-620.

Gibson, I. L., Kinsman, D.J.J., and Walker, G.P.L., 1966. Geology of the Faskrudsfjordur area, eastern Iceland. Greinar Visindanfelag Isl., 2:1-52.

Greeley, R., 1977. Basaltic 'plains' volcanism. In Greeley, R., and King, J. S. (Eds.), Volcanism of the Eastern Snake River Plain, Idaho. NASA, Cr-154621:23-44.

Hinz, K., 1981. A hypothesis of terrestrial catastrophes. Wedges of very thick ocean and dipping layers beneath passive continental marginstheir origin and palaeoenvironment significance. Geol. Jahrb., E22: 3-28.

Hinz, K., Dostman, H. J., and Hanisch, J., 1984. Structural elements of the Norwegian continental margin. Geol. Jahrb., A75:193-221.

Hinz, K., and Schlüter, H.-U., 1978. The geological structure of the western Barents Sea. Mar. Geol., 26:199-230.

Hinz, K., and Weber, J., 1976. Zum geologischen Aufbau des Norwegischen Kontinentalrandes und der Barents-See nach reflexionsseismischen Messungen. Erdöl, Kohle, Erdgas, Petrochemie, Compendium 1975/76: 3-29.

Karson, J. A., 1984. Variations in extensional faulting along the MidAtlantic Ridge. EOS, 65:1114.

Mutter, J. C., Talwani, M., and Stoffa, P. L., 1982. Origin of seaward dipping reflectors in oceanic crust off the Norwegian margin by 'subaerial sea-floor spreading'. Geology, 10:353-357. , 1984. Evidence for a thick oceanic crust adjacent to the Norwegian margin. Geol. Soc. Am. Bull., 95:1135-1149.
Palmason, G., 1980. A continuum model of crustal generation in Iceland: kinematic aspects. J. Geophys. 47: 7-18.

Palmason, G., and Saemundsson, K., 1974. Iceland in relation to the Mid-Atlantic Ridge. Ann. Rev. Earth Planet. Sci., 2:25-50.

Roberts, D. G., Backman, J., Morton, A. C., Murray, J. W., and Keene, J. B., 1984. Evolution of volcanic rifted margins: synthesis of Leg 81 results on the west margin of the Rockall Plateau. In Roberts, D. G., Schnitker, D., et. al., Init. Repts. DSDP, 81: Washington (U.S. Govt. Printing Office), 883-911.

Skogseid J., and Eldholm O., 1987. Early Cenozoic crust at the Norwegian continental margin and the conjugate Jan Mayen Ridge. $J$. Geophys. Res., 92:1147-1149.

Sellevoll, M. A., and Mokhtari, M., 1988. An intra-oceanic crustal seismic reflecting zone below the dipping reflectors on Lofoten margin. Geology, 16: 666-668.

Soper, N. J., Downie, C., Higgins, A. C., and Costa, L. I., 1976. Biostratigraphic ages of Tertiary basalts on the east Greenland continental margin and their relationship to plate separation in the north-east Atlantic. Earth Planet. Sci. Lett., 32:149-157.

Talwani, M., 1978. Distribution of basement under the eastern North Atlantic Ocean and the Norwegian Sea. Geol. J. (Spec. Issue), 5: 347-376.

Talwani, M., Mutter, J., and Eldholm, O., 1981. The initiation of opening of the Norwegian Sea. Oceanologica Acta, SP:23-30.

Talwani, M., Mutter, J. C., and Hinz, K., 1983. Ocean Continent boundary under the Norwegian continental margin. In Bott, M.H.P., Saxov, S., Talwani, M., and Thiede, J. (Eds.), Structure and development of the Greenland Scotland Ridge-new methods and concepts: New York (Plenum Press), 121-131.

Upton, B.G.J., Emeleus, C. H., and Hald, N., 1980. Tertiary volcanism in northern E. Greenland: Gauss Halvo and Hold with Hope. J. Geol. Soc. London, 137:491-508.

Upton, B.G.J., Emeleus, C. H., and Beckinsale, R. D., 1984. Petrology of the northern East Greenland Tertiary flood basalts: Evidence from Hold with Hope and Wollaston Foreland. J. Petrol., 25:151-184.

Walker, G.P.L., 1959. Geology of the Reydarfjørdur area, eastern Iceland. Q. J. Geol. Soc. London, 114:367-393.

Walker, G.P.L., 1960. Zeolite zones and dike distribution in relation to the structure of the basalts of eastern Iceland. J. Geol., 68: 515-528.

White, R. S., Spence, G. D., Fowler, S. R., McKenzie, D. P., Westbrook, G. K., and Bowen, A. N., 1987. Magmatism at rifted continental margins. Nature, 330:439-444.

Date of initial receipt: 5 March 1987

Date of acceptance: 4 November 1988

Ms 104B-195 
A

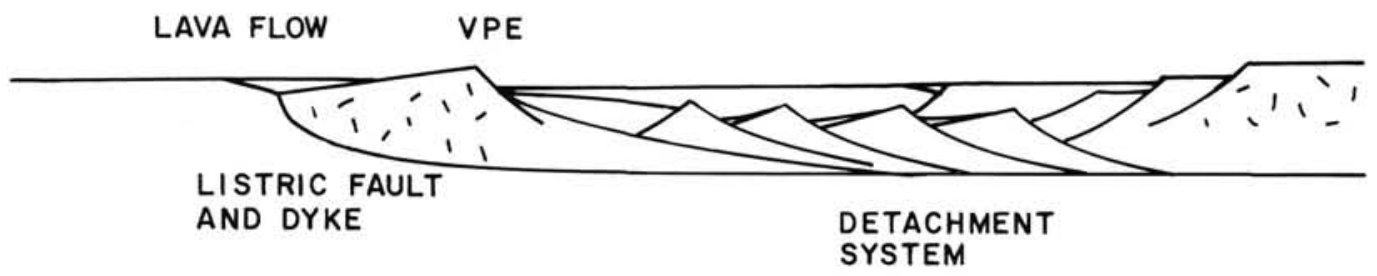

B

SYNCLINAL TERRESTRIAL

LAVA PILE

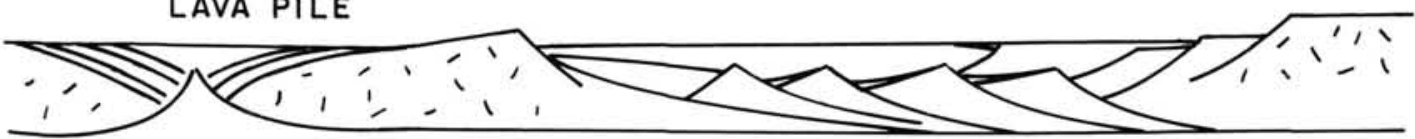

C

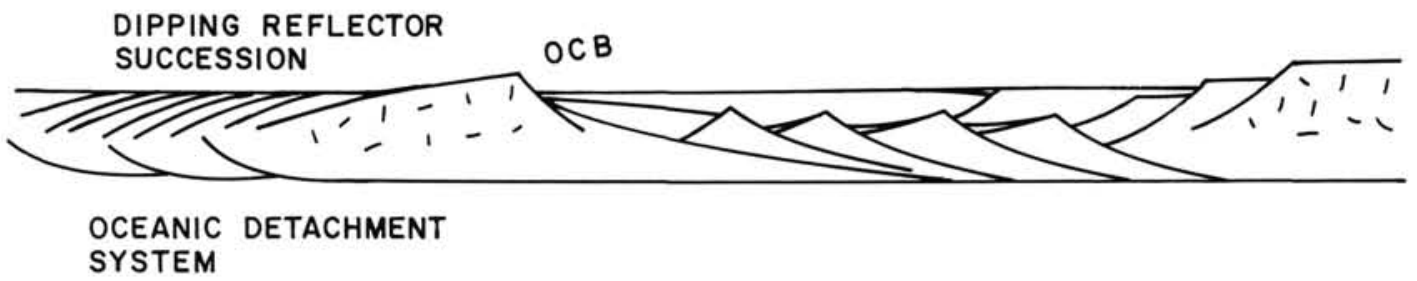

Figure 2. Diagrammatic model for the development of the dipping reflector sequence: A. An initial eruptive event from a single dike, intruded along one of the faults during extensional deformation. This event involves both the extrusion of a lava, shown covering the fault, and the rotation of the pre-existing crustal section. The extension is the result of both the rotation and the separation along the line of the fault. B. The development of a complementary fault system and the eruption of further lavas. Rotation along the listric fault system leads to the formation of a synclinal lava pile. C. Further repeated eruptions associated with listric faulting, and rotation of the pre-existing lavas and dikes. 